University of Wollongong

Research Online

Faculty of Engineering and Information

Faculty of Engineering and Information

Sciences - Papers: Part A

Sciences

2013

Strength and bonding in reduced ironsand-coal compacts

R J. Longbottom

University of Wollongong, rayl@uow.edu.au

B J. Monaghan

University of Wollongong, monaghan@uow.edu.au

S A. Nightingale

University of Wollongong, sharon@uow.edu.au

J G. Mathieson

BlueScope Steel Research

Follow this and additional works at: https://ro.uow.edu.au/eispapers

Part of the Engineering Commons, and the Science and Technology Studies Commons

Research Online is the open access institutional repository for the University of Wollongong. For further information contact the UOW Library: research-pubs@uow.edu.au 


\title{
Strength and bonding in reduced ironsand-coal compacts
}

\author{
Abstract \\ In this investigation, the strength and bonding within reduced ironsand-coal compacts were studied, with \\ the aim of better understanding the binding mechanisms in the reduced compacts and, based on this \\ understanding, to improve their strength. Ironsand ore and sub-bituminous coal were mixed and pressed \\ into compacts, which were reduced by heating in a thermogravimetric furnace to temperatures between \\ 1273 and $1573 \mathrm{~K}$ under argon. The progress of the reaction was monitored by measuring the weight loss \\ with time. The reduced compacts were found to have low strength in compression testing. The main form \\ of bonding between the reduced ironsand particles in the compact was by the formation of a slag-like \\ material. Increasing the final reduction temperature was found to have a profound effect on the strength \\ of the compacts by promoting the formation of this slag-like material.

\section{Keywords} \\ compacts, coal, ironsand, strength, reduced, bonding \\ Disciplines \\ Engineering | Science and Technology Studies

\section{Publication Details} \\ Longbottom, R. J., Monaghan, B. J., Nightingale, S. A. \& Mathieson, J. G. 2013, 'Strength and bonding in \\ reduced ironsand-coal compacts', Ironmaking and Steelmaking, vol. 40, no. 5, pp. 381-389.
}




\section{Strength and Bonding in Reduced Ironsand-Coal Compacts}

Raymond J. Longbottom, University of Wollongong, PYROmetallurgical Research Group, University of Wollongong, Wollongong, NSW 2522, Australia

Brian J. Monaghan, University of Wollongong, PYROmetallurgical Research Group, University of Wollongong, Wollongong, NSW 2522, Australia

Sharon A. Nightingale, University of Wollongong, PYROmetallurgical Research Group, University of Wollongong, Wollongong, NSW 2522, Australia

John G. Mathieson, BlueScope Steel Research, P.O. Box 202, Port Kembla, NSW 2505, Australia 


\begin{abstract}
In this investigation the strength and bonding within reduced ironsand-coal compacts were studied. The aim of the study was to better understand the binding mechanisms in the reduced compacts and, based on this understanding, to improve on their strength.

Ironsand ore and sub-bituminous coal were mixed and pressed into compacts which were reduced by heating in a thermogravimetric furnace (TGA) to temperatures between 1273$1573 \mathrm{~K}$ under argon. The progress of the reaction was monitored by measuring the weight loss with time. The reduced compacts were found to have low strength in compression testing. The main form of bonding between the reduced ironsand particles in the compact was by the formation of a slag-like material. Increasing the final reduction temperature was found to have a profound effect on the strength of the compacts by promoting the formation of this slag-like material.
\end{abstract}

Keywords: direct reduction; ironsand; titanomagnetite; iron ore-coal compact; bonding 


\section{Introduction}

Climate change and the emissions of gases such as carbon dioxide, as well as rising energy costs, are issues of increasing importance to the steel industry. With the greater pressures on the steel industry to reduce the consumption of carbon to provide a corresponding decrease in the emission of carbon dioxide, there has been increasing interest in the use of iron ore-coal compacts in ironmaking processes.

The interest in iron ore-coal compacts is due to their advantage of having the iron oxides and carbonaceous reductant in intimate contact. This close contact between the reactants generally has the effect of increasing the reduction rate ${ }^{1-6}$. Iron ore-carbon compacts are being utilised in new ironmaking processes such as FASTMET, ITmk3 or HiQIP ${ }^{7}$.

As well as the faster reduction kinetics, another advantage of using iron ore-carbon compacts for the reduction of iron ore is that a wide variety of both iron sources and carbonaceous materials can be used. The use of iron ore-carbon compacts allows the use of different iron sources such as iron ore fines, low grade iron ores ${ }^{6}$, plant waste ${ }^{3,8}$ or magnetite ores ${ }^{9}$. The use of different carbon sources such as coal, coke ${ }^{4}$, biomass ${ }^{10,11}$ and plastic waste ${ }^{12-14}$ have also been investigated.

In this study the focus is on the use of an ironsand, a titanomagnetite ore in the form of fairly uniformly sized grains. The ironsand ore is significantly different to conventional hematite iron ores, containing high amounts of titanium and with the iron contained in a magnetiteulvöspinel $\left(\mathrm{Fe}_{3} \mathrm{O}_{4}-\mathrm{Fe}_{2} \mathrm{TiO}_{4}\right)$ solid solution ${ }^{15}$. This ore has significantly different reduction characteristics than hematite ores ${ }^{16-25}$. The chemistry and morphology of ironsand have a large effect on its reduction behaviour. Previous studies have shown that carbothermal reduction of ironsand is slower than for a typical hematite ore ${ }^{26}$. 
There have been few published studies into the strength of reduced iron ore-coal compacts. These compacts need sufficient strength to withstand discharge, storage and handling that may occur during transfer from the reduction unit to the melting furnace. Takano and Mourão ${ }^{27}$ studied the use of cement as a binder in iron ore-coal compacts. They found that when cement is used as a binder, the strength of the compact after heating is related to the strength of the green compacts. They also reported that at higher reduction temperatures, above $1573 \mathrm{~K}$, that the sintering of the reduced iron begins to play an important role in the strength of the compacts. Murakami, et al. ${ }^{28}$ published microstructures of reduced compacts in which at higher temperatures the metallic iron is held together by a slag phase.

The effect of atypical raw materials in iron ore-coal compacts on the strength of the reduced compacts has not been extensively studied. Tanaka, et al. ${ }^{29}$ studied iron ore-coal compacts with high coal contents. They found that the strength and density of the reduced compacts decreased with increasing coal content. Strength in these compacts was either due to a metal or carbon matrix, depending on the composition of the compact.

The aim of this study is to develop an understanding of the reduction of ironsand-coal compacts and how the strength of the reduced compacts is generated. The kinetics of reduction of ironsand-coal compacts was assessed in the temperature range 1273-1573K and the reduced compacts were characterised in terms of strength and microstructure. The effects of changing the coal blend and the use of rice husks were also tested with a view to understanding possible changes in the raw materials. 


\section{Experimental}

Ironsand-coal compacts were prepared from three different mixtures of raw materials for use in reduction trials. The composition of the different compact types is given in Table 1 . The different compacts were prepared to assess the effects of additions on the different types of bonding within the reduced compacts. Compact \#1 was the base case; compact \#2 tested the effect of the addition of a more fluid coking coal to the coal blend on the formation of a remnant carbon structure in the reduced compacts; and compact \#3 tested the effect of the addition of rice husks on the formation of an oxide phase in the reduced compacts. The compositions of the raw materials are given in Tables 2 and 3.

The compacts were prepared by initially mixing the dry ingredients together. The wet ingredients were then added to the dry mixture, and then mixed. Molasses and water were added as binders. The molasses used was massecuite A. A nominal $25 \mathrm{~g}$ of the resulting mixture was pressed into $25 \mathrm{~mm}$ diameter cylinders using a pressure of $6.9 \mathrm{MPa}$ for 30 seconds. After pressing, the compacts were dried and stored overnight in an oven at approximately $383 \mathrm{~K}$.

Reduction of the ironsand-coal compacts was conducted by heating the compacts under argon in a thermogravimetric analysis (TGA) system. A schematic of the experimental set up is shown in Fig. 1. In the reduction experiments both the effect of temperature and compact material on the reduction and strength and microstructure of the reduced compacts were evaluated. A base case was established, reducing compact \#1 at 1573K, against which the effect of the different variables could be compared. Details of the experimental plan are given in Table 4.

The ironsand-coal compacts were heated at $10 \mathrm{~K} \min ^{-1}$ under high purity argon, and then held at the maximum temperature for at least 30 minutes or until the weight of the sample changed 
less than $0.1 \mathrm{~g}$ over 5 minutes. The compacts were held inside an alumina crucible that had holes machined into the sides and bottom to allow the ingress and exit of gas. The initial weight of the compact was measured before placing it into the crucible. After the reduction at temperature, the sample was cooled to room temperature under argon. The crucible containing the compact was removed from the furnace, and the compact carefully removed from the crucible. The weight of the reduced compact was measured. The reduced compacts were then used for strength measurements or for mounting for characterisation of the microstructures by scanning electron microscopy (SEM) combined with energy dispersive spectroscopy (EDS) for elemental analysis.

The metallisation of the reduced compacts was calculated subject to the following assumptions:

- Volatiles were completely removed from the coal and played no part in the reduction;

- Calcination of the hydrated lime was complete; and

- The molasses was reacted from the compact.

These accounted for weight changes due to other processes other than the reactions between iron oxides and carbon. Metallic iron was formed from the ore by the reduction of magnetite or ulvöspinel, with the overall equations which do not represent the reduction mechanism shown in the reactions 1 and 2 .

$$
\begin{aligned}
& 1 / 3 \mathrm{Fe}_{3} \mathrm{O}_{4}+4 / 3 \mathrm{C} \rightarrow \mathrm{Fe}+4 / 3 \mathrm{CO}_{(\mathrm{g})} \\
& 1 / 2 \mathrm{Fe}_{2} \mathrm{TiO}_{4}+\mathrm{C} \rightarrow \mathrm{Fe}+1 / 2 \mathrm{TiO}_{2}+\mathrm{CO}_{(\mathrm{g})}
\end{aligned}
$$

The metallisation of the compacts was calculated from the mass change of the sample after reaction, using equation 3. Metallisation of the DRI, as opposed to a degree of reduction, 
gives more information about its value as a product for subsequent steelmaking processes as it takes the form of the iron into account.

$$
m e t=\frac{\frac{3}{4} \cdot \frac{M_{\mathrm{Fe}}}{M_{\mathrm{CO}}}\left(\Delta m_{\mathrm{exp}}-m_{v o l}-m_{\mathrm{lim} e}-m_{m o l}-\frac{2 m_{\mathrm{TiO}} \cdot M_{\mathrm{CO}}}{M_{\mathrm{TiO}_{2}}}\right)+\frac{2 m_{\mathrm{TiO}_{2}} \cdot M_{\mathrm{Fe}}}{M_{\mathrm{TiO}_{2}}}}{m_{\mathrm{Fe}, \text { ironsand }}+m_{\mathrm{Fe}, \text { ash }}}
$$

Where met is the metallisation, $\Delta m_{\exp }$ is the experimental weight change, $m_{v o l}$ is the mass of volatiles in the compact, $m_{\text {lime }}$ is the mass change associated with the calcination of the hydrated lime, $m_{m o l}$ is the mass of molasses in the compact, $m_{\mathrm{TiO}_{2}}$ is the total mass of $\mathrm{TiO}_{2}$ in the compact calculated from the ironsand and compact composition, $m_{F e, \text { ironsand }}$ is the total mass of iron in the ironsand, $m_{F e, a s h}$ is the total mass of iron in the coal ash, and $M_{F e}, M_{C O}$ and $M_{\mathrm{TiO}_{2}}$ are the molar masses of $\mathrm{Fe}, \mathrm{CO}$ and $\mathrm{TiO}_{2}$, respectively.

The strength of the reduced compacts was tested by compression testing using an Instron 5566 bench top unit. The load on the sample was increased at $1 \mathrm{~N} \mathrm{~s}^{-1}$ until sample failure. The peak load reached was reported as the compressive strength of the sample. The load was measured by a $1 \mathrm{kN}$ load cell.

Both unreduced and reduced ironsand-coal compacts were mounted in epoxy resin. These were sectioned approximately half way along the axis, then ground and polished to a $1 \mu \mathrm{m}$ diamond finish. The polished samples were then examined under a Leica DMRM optical microscope and a JEOL JSM 6490LV SEM/EDS. EDS was used to provide semi-quantitative elemental analyses of different points within the cross-sections of the samples and elemental mapping. 


\section{Results}

\subsection{Reduction of Ironsand-Coal Compacts}

The fractional weight change during reduction at $1273-1573 \mathrm{~K}$ is shown in Fig. 2, where fractional weight change is defined in equation 4.

fractional weight change $=\frac{m_{t}-m_{i}}{m_{i}}$

Where $m_{i}$ is the initial mass of the sample and $m_{t}$ is the mass of the sample at time $t$.

It can be seen that there were two separate regions of decreasing weight occurring at different temperature ranges. The first occurred at lower temperatures, and was due to devolatilisation of the coal, and finished at a fractional weight change of approximately 0.1 . The second occurred at medium temperatures and continued until the plateau temperature was reached, corresponding to the reduction of the iron oxides, and gave a final fractional weight change of $0.41-0.42$ at $1573 \mathrm{~K}$.

The effect on the final temperature reached during reduction was examined by reducing compact \#1 samples at $1273 \mathrm{~K}, 1373 \mathrm{~K}$ and $1473 \mathrm{~K}$, and compared to a compact \#1 sample reduced at the baseline temperature of $1573 \mathrm{~K}$. The fractional weight change during reduction at different temperatures is shown in Fig. 2. There was no real difference between the curves at lower temperatures. Changes occurred when the different maximum temperatures were reached. It will be noted that the sample reduced at $1273 \mathrm{~K}$ was reduced slightly more slowly than those reduced at higher temperatures. Both this sample and that reduced at $1373 \mathrm{~K}$ reached a lower final weight change than at $1473 \mathrm{~K}$ and $1573 \mathrm{~K}$. 
The weight change curves for compacts prepared from different mixtures, reduced at $1573 \mathrm{~K}$, are shown in Fig. 3. There was little difference in the curves for the different compact types, with all three types showing the same basic shape and only marginally different weight losses.

The metallisation of the reduced ironsand-coal compacts was calculated from the weight change of the compact after heating. The calculated metallisation from the weight change curves of compacts reduced under different conditions is given in Table 5.

\subsection{Strength of Ironsand-Coal Compacts}

The compressive strength of ironsand-coal compacts was measured both before and after reduction. The peak strength data reported here should not be taken as any more than a representation of zero, low, or some strength in a sample. In this study on the compact strength, only one sample of each type and reduction temperature was examined. The ironsand-coal compacts did not remain cylindrical after reduction. For these reasons the strength values reported here are indicative only. The compressive strengths of the reduced compacts are summarised in Tables 6 and 7.

Photographs of the samples taken after reduction but before compressive testing are also shown in Tables 6 and 7. Some of the samples were too weak to be removed from the TGA crucible in one piece. Other samples also formed irregular shapes after reduction, and were no longer the simple cylindrical shape of the green compacts. This distortion of the compacts during reduction had an effect on the results of the compression testing. The notes on abrasion indicated that material from the compacts could easily be removed by rubbing or sliding the sample, which was avoided as much as possible during handling. 
Green compacts were found to exhibit a reasonable amount of strength, with $1310 \mathrm{kPa}$ required to crush a representative sample. The green compacts were found to be robust, and survived handling well.

The temperature of reduction is a significant factor in the strength of the reduced ironsandcoal compacts, as can be seen from Table 6. At low reduction temperatures, 1273-1373K, the reduced compacts did not have enough strength to be removed from the crucible. At $1473 \mathrm{~K}$ the sample had very little strength, requiring less than $1 \mathrm{~kg}$ to crush it. At $1573 \mathrm{~K}$ the reduced compact displayed some strength, but not enough for survival in transportation within an industrial plant.

From Table 7 it can be seen that the compact type also played a large role in determining the strength of the reduced compacts. Replacement of half of the coal with the fluid coking coal in compact \#2 was found to dramatically lower the strength of the reduced compact.

Replacing half of the paper binder with the rice husks in compact \#3 slightly increased the crush strength of the sample measured. Neither sample could be considered to be strong.

\subsection{Characterisation of Reduced Ironsand-Coal Compacts}

The microstructures of reduced ironsand-coal compacts were characterised by examining polished cross-sections by SEM. Semi-quantitative elemental analysis was conducted on specific points in the samples by EDS along with qualitative analysis by elemental mapping of areas of interest. The microstructures of the reduced compacts were used to observe the way that the compacts were held together, as well as the effect of temperature and compact type on the bonding. 
An SEM image of a type \#1 compact reduced at $1573 \mathrm{~K}$ is shown in Fig. 4. The ironsand grains have been reduced, showing a sponge iron structure. There were varying levels of coarseness of iron sponge. Coarse sponge iron structures were associated with the slag-like material. Ironsand particles were joined together by a slag-like material, by point contact between particles, along an edge of a particle or by completely enveloping several particles. The slag-like material contained two different phases, represented by the two different shades of grey that can be seen. Semi-quantitative elemental analysis was conducted on several points in the cross-section of the reduced compact \#1, shown in Fig. 5. The slag-like material consisted of two phases, the majority being a silicon-rich oxide phase, and the other being predominantly a magnesium silicate. The silicon-rich phase contained quite high levels of calcium oxides, and more of the other gangue elements, such as titanium, than the magnesium silicate. There was little evidence of metallic network formation, with only incipient metal phase bonds having formed. There was no carbonaceous phase bonding.

To examine the effect of temperature on the microstructure, compact \#1 samples reduced at $1273 \mathrm{~K}, 1373 \mathrm{~K}$ and $1473 \mathrm{~K}$ were cross-sectioned and their microstructures compared to those of a samples reduced at the baseline temperature of $1573 \mathrm{~K}$. The samples reduced at $1273 \mathrm{~K}$ and 1373K, shown in Fig. 6, showed little of the slag-like material joining reduced ironsand particles, as seen in the compact reduced at 1573K. An SEM image and EDS analysis of a compact reduced at $1473 \mathrm{~K}$ are shown in Fig. 7. The formation of the slag-like material had begun at this temperature, and it could be seen holding some ironsand grains together. Analysis of the bonding slag-like oxide phase shows that it was predominantly silicon rich. A compact \#2 sample, containing 50\% substitution by the fluid, coking coal, reduced at $1573 \mathrm{~K}$ is seen in Fig. 8. The slag-like material binding ironsand particles together was again present, but in this case mostly by point contact between particles. Again there was no 
evidence of carbonaceous phase bonding, though there is some metallic bonding between ironsand particles.

An SEM image a sample of compact \#3 containing the rice husks as well as elemental analysis of different points within the image are shown in Fig. 9. The rice husks in this study were added as a mixture of large particles and fine dust. There was evidence of the slag-like material holding some ironsand particles together. This slag-like material enveloped several of the reduced ironsand particles, holding them together, as could be seen with the baseline type. The slag-like material in this image appeared to consist of three different oxide phases, one rich in silicon, one richer in magnesium and the other rich in calcium and titanium, which is likely to be high melting point perovskite $\left(\mathrm{CaO} \cdot \mathrm{TiO}_{2}\right)$. 


\section{Discussion}

The reduced ironsand-coal compacts that were produced during this study were not strong enough for use in industrial processes, for example for transport to an electric arc furnace or melter unit. Some of the reduced samples had low strength, but others had very little or none. Any strength in the compacts was due to binding together of the individual particles and components of the compact. This was made more difficult by consumption of material within the compacts during reduction, increasing the distance between particles.

\subsection{Baseline Conditions}

Under the baseline conditions of a compact \#1 sample reduced at $1573 \mathrm{~K}$, it was found that the sample had a low strength. The reduced ironsand particles were being held together by a slaglike material. The slag-like material mainly consisted of two phases, one rich in silicon and the other rich in magnesium. The majority of this slag-like material was the paler, silicon rich phase. The mass ratio of $\mathrm{SiO}_{2}: \mathrm{MgO}$ in the paler phase was measured to be approximately 3 , while for the darker phase it was approximately 0.5 .

The sources of oxides in the system which could form the basis of the slag-like material were the gangue in the ironsand and the ash from the coal. The majority (over 90\%) of the unreduced oxides in the compact originate from the ironsand. Overall, the ironsand gangue has a mass ratio of $\mathrm{SiO}_{2}: \mathrm{MgO}$ of 0.69 . The ash of the sub-bituminous coal has a mass ratio of $\mathrm{SiO}_{2}: \mathrm{MgO}$ of 10.7 . However, the presence of some individual grains and regions of ironsand grains (inclusions) that were rich in silicon was noted in the original ore. It is likely that the slag-like material has originated from this distinct phase in the original ore, before taking in the other oxides as the temperature and reduction duration increased. This is supported by the amount of oxide material that is trapped within the iron sponge structure that did not contribute to the bonding between the reduced ironsand particles. 


\subsection{Effect of Temperature}

The maximum temperature that was reached during reduction was a very important factor in determining the final strength of the reduced ironsand-coal compacts. At the lower end of the temperature range examined, 1273-1373K, there was little evidence of bonding between the ironsand particles by either the formation of a slag-like material or carbonaceous material. The temperatures seen by these samples during reduction may not have been high enough to form a liquid or for coalescence of the oxide material. At temperatures of $1473 \mathrm{~K}$ and above, the slag-like material was found.

There are significant uncertainties in the solidus and liquidus temperatures in the $\mathrm{CaO}-\mathrm{MgO}-$ $\mathrm{SiO}_{2}-\mathrm{Al}_{2} \mathrm{O}_{3}-\mathrm{TiO}_{\mathrm{x}}$ systems. It is known that for slags containing relatively high amounts of titanium, the liquidus temperature is strongly dependant on the oxidation state of the slag ${ }^{30,31}$.

To assess the liquidus temperatures without titania in the slag-like materials seen in the compacts, the phase diagram for the $\mathrm{CaO}-\mathrm{MgO}-\mathrm{SiO}_{2}$ ternary system was examined. For the composition of the slag-like material (simplified to approximately $32 \mathrm{wt} \% \mathrm{CaO}, 16 \% \mathrm{MgO}$, $52 \% \mathrm{SiO}_{2}$ ) the liquidus temperature was approximately $1623 \mathrm{~K}^{32}$.

To assess the effect of titania on the liquidus temperature, the literature was examined. Ratchev and Belton ${ }^{30}$ report liquidus temperatures in the range of $1823 \mathrm{~K}-1973$ for slags with $21.6 \% \mathrm{Ti}$; increasing with higher proportions of $\mathrm{Ti}^{3+}$. Reduction of the titanium from $\mathrm{Ti}^{4+}$ to $\mathrm{Ti}^{3+}$ was reported to increase the liquidus temperatures by $140 \mathrm{~K}$. However, their titania containing slag compositions are not the same as those seen in the slag-like material found in this study. For titania containing slag compositions similar to those found in this study, Zhao et al. ${ }^{33}$ report a liquidus temperature of approximately $1763 \mathrm{~K}$, measured under argon. These 
liquidus temperatures are significantly higher than the experimental temperatures used in this study. While it is likely that the slag-like material was formed at temperatures between the solidus and liquidus, it also is likely that for the compositions and oxidation state of the slaglike material that the liquidus temperatures are lower than those reported in the literature.

\subsection{Effect of Compact Composition}

Changes to the components of the ironsand-coal compacts were made to examine the effect of the changing the raw materials on the strength of reduced compacts. Additions of a coking coal (compact \#2) and rice husks (compact \#3) were made to examine their effects on the bonding of the ironsand grains in the reduced compacts. These changes were planned to have effects on different phases within the reduced compacts.

The coking coal substituted half of the coal in the compact \#2 composition, as an attempt to improve the bonding of the ironsand particles by the carbonaceous material. It was hoped that the addition of a more fluid coal would allow a coke-like structure to be formed. However, this sample was found to exhibit little strength after reduction. Examination of the microstructure of a reduced compact \#2 sample showed no bonding of the compact by carbonaceous material. It was hoped that a coke-like structure would be formed from the remnant carbonaceous material, bonding the reduced ironsand particles together. However, this coke-like structure was not observed. Any binding between ironsand particles was due to the formation of the slag-like material, with similar phases having similar compositions to those found in the reduced compact \#1 samples. While the coking coal has a very different ash composition to the sub-bituminous coal used in compact \#1, this caused little effect on the composition of the slag-like material. This also indicates that the slag-like material is likely to have formed from the gangue material in the ironsand. 
Rice husks were introduced into the compacts as they can be seen as a cheap, waste-product source of silica and some carbon. It was hoped that by introducing more silica into the compacts more slag-like material would be produced and that the melting point of the slaglike material would be lowered. Both of these could combine to enhance the binding of the ironsand particles by the slag-like material. The microstructure of the reduced compact \#3 sample showed that the slag-like material was again the main source of bonding between the ironsand particles. The composition of the slag-like material measured by EDS was found to be different in this case. While there were different phases seen in the slag-like material as before, for compact \#3 the paler phase that appeared to make up the majority of the slag-like material was significantly richer in silica and lower in both magnesium and calcium oxides than previously measured.

\subsection{Improving Strength of Reduced Compacts}

The compacts were produced from relatively coarse raw materials, both in terms of the coal and the ironsand ore. The coarse raw materials would have contributed to the low strengths of both the green and reduced compacts. A finer particle size distribution, especially of the ironsand, would lead to better contact between particles and enhancement of the compact strength.

Within the reduced compacts there are three phases, the metallic iron, unconsumed remnants of the coal and oxide material from the ore gangue, coal ash and any added fluxes. To improve the strength of reduced ironsand-coal compacts, it is necessary to enhance the bonding of the reduced ironsand particles. Possibilities to enhance the binding within the compacts could utilise any of the existing phases, through consolidation of the metal phase, by the formation a carbonaceous matrix, or by enhancing the formation of the slag-like material. 
In the current samples, little bonding was seen in the metal phase. To improve the sintering of the reduced iron, the temperature of reduction would have to be increased. This has the disadvantage of requiring either more coal or energy, decreasing any reduction in carbon usage and emissions.

The carbon remaining in the reduced compacts was in the form of dense individual particles. This likely explains why the coal type used did not have a significant effect on the strength of the compacts. To promote the formation of a carbonaceous matrix the amount of coking coal used in the compacts should be increased, and the total amount of coal within the compact should be increased to give more excess carbon in the reduced compact.

The formation of the slag-like material can also be promoted, which could be done by one of three ways. These are increasing the temperature of the reduction, increasing the time at temperature, or by the addition of a fluxing agent to the compact.

Both increasing the temperature of the reduction, or the time at temperature, would enhance the formation of the slag-like phase, allowing more ironsand particles to be held together by the slag. Increasing the temperature would require a higher energy input. Increasing the temperature may also cause the oxide material trapped within the sponge structure to contribute to slag formation.

Formation of the slag-like material could also be enhanced by the addition of a flux that would lower the liquidus temperature and provide more slag-like material within the compact. The flux could be chosen such that the slag formed would have a very low liquidus temperature, which may subsequently increase after formation as more of the ore gangue is incorporated into it. This has an advantage in the reduction stage in not needing more or different forms of coal. However, this would have a negative impact at the melting stage, requiring more energy to melt the increased amounts of slag. A significant difficulty with this 
approach is the lack of data to enable a reasonable prediction of the liquidus temperature after fluxing.

The proposed methods to improve the strength of the reduced compacts all have the disadvantage of requiring either more energy or more coal than is currently being used for the production of the current, low strength compacts. However, for this to be a viable industrial practice, improvement of the compact strength is necessary.

\section{Conclusions}

This project was undertaken to develop a technique to produce suitable ironsand-coal compacts, and to examine the strength of these compacts after reduction. The aim of the project was to develop a better understanding of the bonding in the reduced compacts and to improve on the strength of the compacts based on the improved understanding of the bonding.

The reduced ironsand-coal compacts had low strength when tested under compression. The main form of bonding between the reduced ironsand particles was by the formation of a slaglike material at higher temperatures. This slag-like material contained distinct phases. The majority of the slag-like material was found to be in the form of a silica-rich phase also containing lime. This was formed from a silica-rich phase that was found as distinct regions within ironsand particles and as individual grains within the ore. Increasing the final reduction temperature was found to have a profound effect on the strength of the compacts by promoting the formation of this slag-like material.

Changes to the compact mixtures were made to study the effect of the composition on the strength of the compacts. The addition of a fluid, coking coal was made to promote the formation of a coke-like structure that could bind the ironsand particles together. However, there was little evidence of this coke-like material in the final microstructures, and these 
samples showed little strength. The addition of rice husks was done to enhance the formation of the slag-like material and was observed to have some beneficial effect.

\section{Acknowledgements}

This project was funded by the University of Wollongong's BlueScope Steel Metallurgy

Centre. The authors would also like to acknowledge the contribution of Harold Rogers during this project. 


\section{References}

1. M.B. Mourão and C. Takano: Miner. Process. Extr. Metall. Rev., 2003, 24, 183-202.

2. H. Konishi, K. Ichikawa and T. Usui: ISIJ International, 2010, 50 386-389.

3. K. Watanabe, S. Ueda, R. Inoue and T. Ariyama: ISIJ International, 2010, 50, 524-530.

4. S. Ueda, K. Yanagiya, K. Watanabe, T. Murakami, R. Inoue and T. Ariyama: ISIJ International, 2009, 49, 827-836.

5. M. Kawanari, A. Matsumoto, R. Ashida and K. Miura: ISIJ International, 2011, 51, $1227-$ 1233.

6. K. Miura, K. Miyabayashi, M. Kawanari and R. Ashida: ISIJ International, 2011, 51, 12341239.

7. S. Inaba and Y. Kimura: ISIJ International, 2004, 44, 2112-2114.

8. H. Tsutsumi, S. Yoshida and M. Tetsumoto: Kobelco Technology Review, 2010, 85-92.

9. K. Ishizaki, K. Nagata and Y. Hayashi: ISIJ International, 2007, 47, 817-822.

10. Y. Ueki, K.I. Ohno, T. Maeda, K. Nishioka and M. Shimizu: Fuel, 2010, (in press).

11. S. Ueda, S. Watanabe, K. Yanagiya, T. Murakami, R. Inoue and T. Ariyama: ISIJ International, 2009, 49, 1505-1512.

12. K. Nishioka, T. Taniguchi, Y. Ueki, K.I. Ohno, T. Maeda and M. Shimizu: ISIJ International, 2007, 47, 602-607.

13. T. Murakami and E. Kasai: ISIJ International, 2011, 51, 9-13. 
14. Y. Ueki, K.I. Ohno, T. maeda, K. Nishioak and M. Shimizu: ISIJ International, 2008, 48, 1670-1675.

15. J.B. Wright: New Zealand J. Geology and Geophysics, 1964, 7, 424-444.

16. G.D. McAdam, R.E.A. Dall and T. Marshall: N.Z. J. Sci., 1969, 12, 649-668.

17. G.D. McAdam, R.E.A. Dall and T. Marshall: N.Z. J. Sci., 1969, 12, 669-686.

18. G.D. McAdam: Ironmaking and Steelmaking, 1974, 138-150.

19. E. Park: Ph.D. Thesis University of New South Wales, Sydney, Australia, 2002.

20. E. Park and O. Ostrovski: Proc. of the $1^{\text {st }}$ Int. Conf. on Advanced Materials Processing, Institute of Materials Engineering, Australasia, 2000, 87-94.

21. E. Park and O. Ostrovski: ISIJ International, 2003, 43, 1316-1325.

22. E. Park and O. Ostrovski: ISIJ International, 2004, 44, 74-81.

23. E. Park and O. Ostrovski: ISIJ International, 2004, 44, 999-1005.

24. E. Park, S.B. Lee, O. Ostrovski, D.J. Min and C.H. Rhee: ISIJ International, 2004, 44, 214-216.

25. R.J. Longbottom, O. Ostrovski and E. Park: ISIJ International, 2006, 46, 641-646.

26. N.I. Krasnova and Y.L. Krezer: Eur. J. Mineral., 1995, 7, 1361-1372.

27. C. Takano and M.B. Mourão: Miner. Process. Extr. Metall. Rev., 2003, 24, 233-252.

28. T. Murakami, T. Nishimura and E. Kasai: ISIJ International, 2009, 49, 1686-1693. 
29. Y. Tanaka, T. Ueno, K. Okumura and S. Hayashi: ISIJ International, 2011, 51, 1240 1246.

30. I.P. Ratchev and G.R. Belton: Proc. $5^{\text {th }}$ Int. Conf. on Molten Slags, Fluxes and Salts, ISS, Warrendale, PA, 1997, 387-393.

31. G. Tranell, O. Ostrovski and S. Jahanshahi: Metall. Mater. Trans. B, 2002, 33B, 61-67.

32. M. Kowalski, P.J. Spencer and D. Neuschütz: Slag Atlas, ed. by Verin Duetscher Eisenhüttenleute (VDEh), Verlag Stahleisen GmbH, Düsseldorf, 1995, 70.

33. B. Zhao, E. Jak and P. Hayes: Proc. $8^{\text {th }}$ Int. Conf. on Molten Slags, Fluxes and Slats, Quebecor World Chile, 2009, 71-82. 


\section{List of Captions}

Figure 1 - Schematic of the TGA set up used for the reduction of experimental compacts.

Figure 2 - Fractional weight change during reduction of compact \#1 samples at different temperatures.

Figure 3 - Weight change curves for compacts of different types reduced at $1573 \mathrm{~K}$.

Figure 4 - Higher magnification SEM images of compact \#1 reduced at 1573K, showing sponge iron, slag-like material and remnants of coal.

Figure 5 -Elemental analysis points within a compact \#1 sample reduced at 1573K. Semiquantitative analysis in atomic percent.

Figure 6 - SEM images of a reduced compact \#1 sample. (a) Reduced at 1273K, medium magnification overview showing reduced titanomagnetite and coal remnants; (b) reduced at 1373K, medium magnification image showing sponge iron structure, gangue particles and carbonaceous material.

Figure 7 - SEM images of a compact \#1 sample reduced at 1473K. Medium magnification showing sponge structure of reduced and partially reduced titanomagnetite.

Figure 8 - Higher magnification SEM images of a compact \#2 sample reduced at $1573 \mathrm{~K}$. Medium magnification image showing slag-like material binding reduced titanomagnetite particles.

Figure 9 - EDS elemental analysis of points within a compact \#3 sample reduced at $1573 \mathrm{~K}$. Semi-quantitative analysis given in atomic percent. 
Table 1 - Constituents of the compact types and their proportions (dry weights).

Table 2-Composition of the ironsand.

Table 3 -Proximate and ash analyses of the coal samples.

Table 4 - Experimental plan.

Table 5 - Metallisation of reduced compacts.

Table 6 - Compressive strength of samples of compact \#1 reduced at varying temperatures.

Table 7 - Compressive strength of compacts of different types, reduced at $1573 \mathrm{~K}$. 
Table 1 - Constituents of the compact types and their proportions (dry weights).

\begin{tabular}{|l|l|l|l|}
\hline & $\begin{array}{l}\text { compact \#1 } \\
\text { (wt\%) }\end{array}$ & $\begin{array}{l}\text { compact \#2 } \\
\text { (wt\%) }\end{array}$ & $\begin{array}{l}\text { compact \#3 } \\
\text { (wt\%) }\end{array}$ \\
\hline ironsand & 70.7 & 70.7 & 70.7 \\
\hline $\begin{array}{l}\text { sub-bituminous } \\
\text { coal }\end{array}$ & 23.5 & 11.75 & 23.5 \\
\hline coking coal & - & 11.75 & - \\
\hline lime (CaO) & 2.1 & 2.1 & 2.1 \\
\hline paper & 1.5 & 1.5 & 0.75 \\
\hline rice husks & - & - & 0.75 \\
\hline water & 1.7 & 1.7 & 1.7 \\
\hline molasses & 1.5 & 1.5 & 1.5 \\
\hline
\end{tabular}


Table 2-Composition of the ironsand.

\begin{tabular}{|l|l|}
\hline & Weight \% \\
\hline $\mathrm{Fe}$ & 59.12 \\
\hline $\mathrm{TiO}_{2}$ & 7.87 \\
\hline $\mathrm{Al}_{2} \mathrm{O}_{3}$ & 3.77 \\
\hline $\mathrm{MgO}$ & 2.85 \\
\hline $\mathrm{SiO}$ & 1.97 \\
\hline $\mathrm{CaO}$ & 0.41 \\
\hline $\mathrm{MnO}$ & 0.63 \\
\hline $\mathrm{V}_{2} \mathrm{O}_{3}$ & 0.49 \\
\hline $\mathrm{P}$ & 0.035 \\
\hline
\end{tabular}


Table 3 -Proximate and ash analyses of the coal samples.

\begin{tabular}{|c|c|c|c|}
\hline Analysis & Component & $\begin{array}{l}\text { Sub-bituminous coal } \\
-75 \mu \mathrm{m}(w t \%)\end{array}$ & $\begin{array}{l}\text { Coking coal } \\
-75 \mu \mathrm{m}(w \mathrm{t} \%)\end{array}$ \\
\hline \multirow[t]{3}{*}{ Proximate analysis } & Inherent Moisture & 7.6 & 1.5 \\
\hline & Ash & 5.2 & 10.5 \\
\hline & Volatile Matter & 40.8 & 30.6 \\
\hline \multirow[t]{14}{*}{ Ash analysis } & Silicon as $\mathrm{SiO}_{2}$ & 34.8 & 53.9 \\
\hline & Aluminium as $\mathrm{Al}_{2} \mathrm{O}_{3}$ & 12.3 & 32 \\
\hline & Iron as $\mathrm{Fe}_{2} \mathrm{O}_{3}$ & 18.7 & 4.34 \\
\hline & Calcium as $\mathrm{CaO}$ & 16.8 & 2.14 \\
\hline & Magnesium as $\mathrm{MgO}$ & 3.23 & 0.89 \\
\hline & Sodium as $\mathrm{Na}_{2} \mathrm{O}$ & 1.34 & 0.59 \\
\hline & Potassium as $\mathrm{K}_{2} \mathrm{O}$ & 0.36 & 1.22 \\
\hline & Titanium as $\mathrm{TiO}_{2}$ & 2.47 & 2.20 \\
\hline & Manganese as $\mathrm{Mn}_{3} \mathrm{O}_{4}$ & 0.24 & 0.044 \\
\hline & Sulfur as $\mathrm{SO}_{3}$ & 8.8 & 1.39 \\
\hline & Phosphorus as $\mathrm{P}_{2} \mathrm{O}_{5}$ & 0.14 & 0.51 \\
\hline & Strontium as $\mathrm{SrO}$ & 0.14 & 0.16 \\
\hline & Barium as $\mathrm{BaO}$ & 0.13 & 0.12 \\
\hline & Zinc as $\mathrm{ZnO}$ & 0.03 & 0.04 \\
\hline
\end{tabular}


Table 4 - Experimental plan.

\begin{tabular}{|l|l|l|}
\hline Variable & Compact type & Temperature \\
\hline base case & compact \#1 & $1573 \mathrm{~K}$ \\
\hline temperature & compact \#1 & $1273,1373,1473 \mathrm{~K}$ \\
\hline coking coal & $\begin{array}{l}\text { compact \#2, replaces } \\
50 \% \text { of coal }\end{array}$ & $1573 \mathrm{~K}$ \\
\hline rice husks & $\begin{array}{l}\text { compact \#3, replaces } \\
50 \% \text { of paper fibre }\end{array}$ & $1573 \mathrm{~K}$ \\
\hline
\end{tabular}


Table 5 - Metallisation of reduced compacts.

\begin{tabular}{|l|l|l|}
\hline Sample & $\begin{array}{l}\text { Final fractional } \\
\text { weight change }\end{array}$ & $\begin{array}{l}\text { Metallisation } \\
(\%)\end{array}$ \\
\hline Compact \#1,1573K & 0.420 & 97 \\
\hline Compact \#1,1573K & 0.415 & 96 \\
\hline Compact \#1,1573K & 0.424 & 99 \\
\hline Compact \#1,1273K & 0.393 & 89 \\
\hline Compact \#1, 1373K & 0.388 & 87 \\
\hline Compact \#1,1473K & 0.408 & 94 \\
\hline Compact \#2, 1573K & 0.402 & 97 \\
\hline Compact \#3,1573K & 0.409 & 94 \\
\hline
\end{tabular}


Table 6 - Compressive strength of samples of compact \#1 reduced at varying temperatures.

\begin{tabular}{|c|c|c|c|}
\hline Sample & Picture & Strength & Notes \\
\hline $\begin{array}{l}\text { Compact \#1, } \\
\text { reduced } 1273 \mathrm{~K}\end{array}$ & & - & $\begin{array}{l}\text { Reduced compact crumbled into very } \\
\text { small particles when removed from } \\
\text { crucible. No strength. }\end{array}$ \\
\hline $\begin{array}{l}\text { Compact \#1, } \\
\text { reduced 1373K }\end{array}$ & & - & $\begin{array}{l}\text { Reduced compact broke into small } \\
\text { pieces during removal from crucible. } \\
\text { No strength. }\end{array}$ \\
\hline $\begin{array}{l}\text { Compact \#1, } \\
\text { reduced } 1473 \mathrm{~K}\end{array}$ & & $18.3 \mathrm{kPa}$ & $\begin{array}{l}\text { Reduced compact fragile, handling with } \\
\text { extreme care, easily abraded. Low } \\
\text { strength. }\end{array}$ \\
\hline $\begin{array}{l}\text { Compact \#1, } \\
\text { reduced } 1573 \mathrm{~K}\end{array}$ & & $297 \mathrm{kPa}$ & $\begin{array}{l}\text { Reduced compact can be handled, but } \\
\text { carefully, and can be abraded. Some } \\
\text { strength. }\end{array}$ \\
\hline
\end{tabular}


Table 7 - Compressive strength of compacts of different types, reduced at $1573 \mathrm{~K}$.

\begin{tabular}{|c|c|c|c|}
\hline Sample & Picture & Strength & Notes \\
\hline $\begin{array}{l}\text { Compact \#1, } \\
\text { reduced }\end{array}$ & & $297 \mathrm{kPa}$ & $\begin{array}{l}\text { Reduced compact can be handled, but } \\
\text { carefully, and can be abraded. Some } \\
\text { strength. }\end{array}$ \\
\hline $\begin{array}{l}\text { Compact \#2, } \\
\text { reduced }\end{array}$ & & $30.9 \mathrm{kPa}$ & $\begin{array}{l}\text { Reduced compact rather fragile, handling } \\
\text { with care, easily abraded. Low strength. }\end{array}$ \\
\hline $\begin{array}{l}\text { Compact \#3, } \\
\text { reduced }\end{array}$ & & $686 \mathrm{kPa}$ & $\begin{array}{l}\text { Reduced compact can be handled, but } \\
\text { carefully, and can be abraded. Some } \\
\text { strength. }\end{array}$ \\
\hline
\end{tabular}




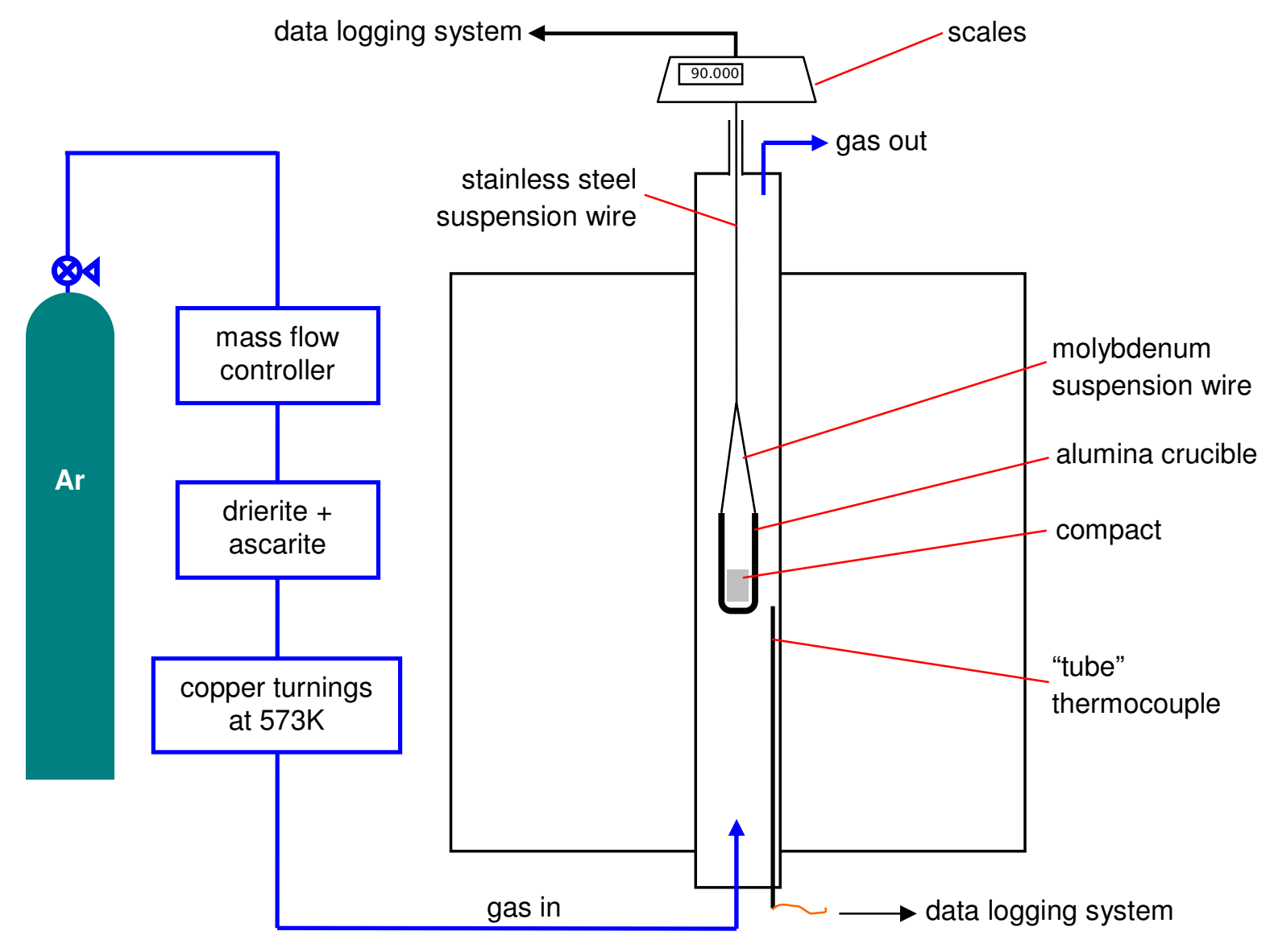

Figure 1 - Schematic of the TGA set up used for the reduction of experimental compacts. 


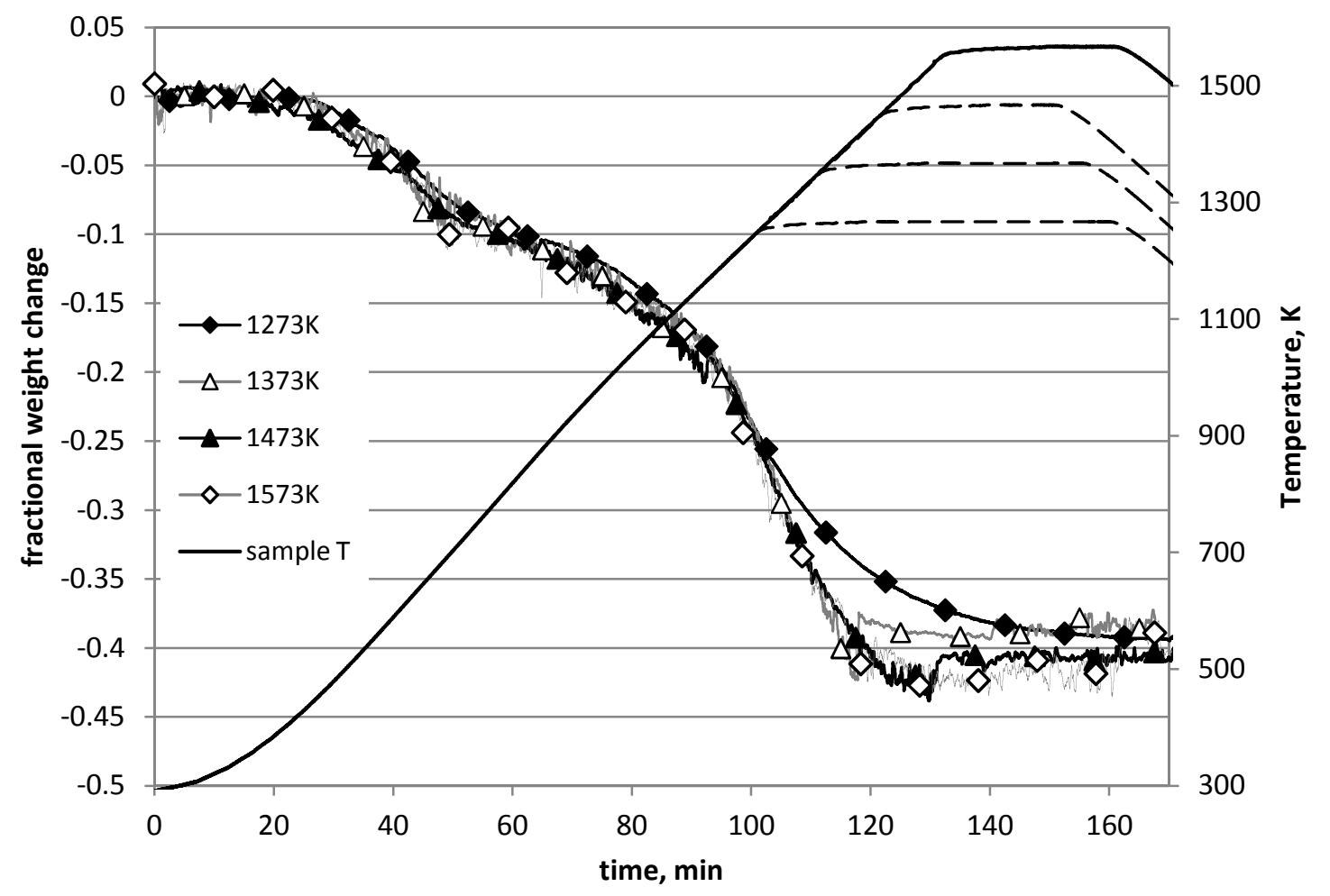

Figure 2 - Fractional weight change during reduction of compact \#1 samples at different temperatures. 


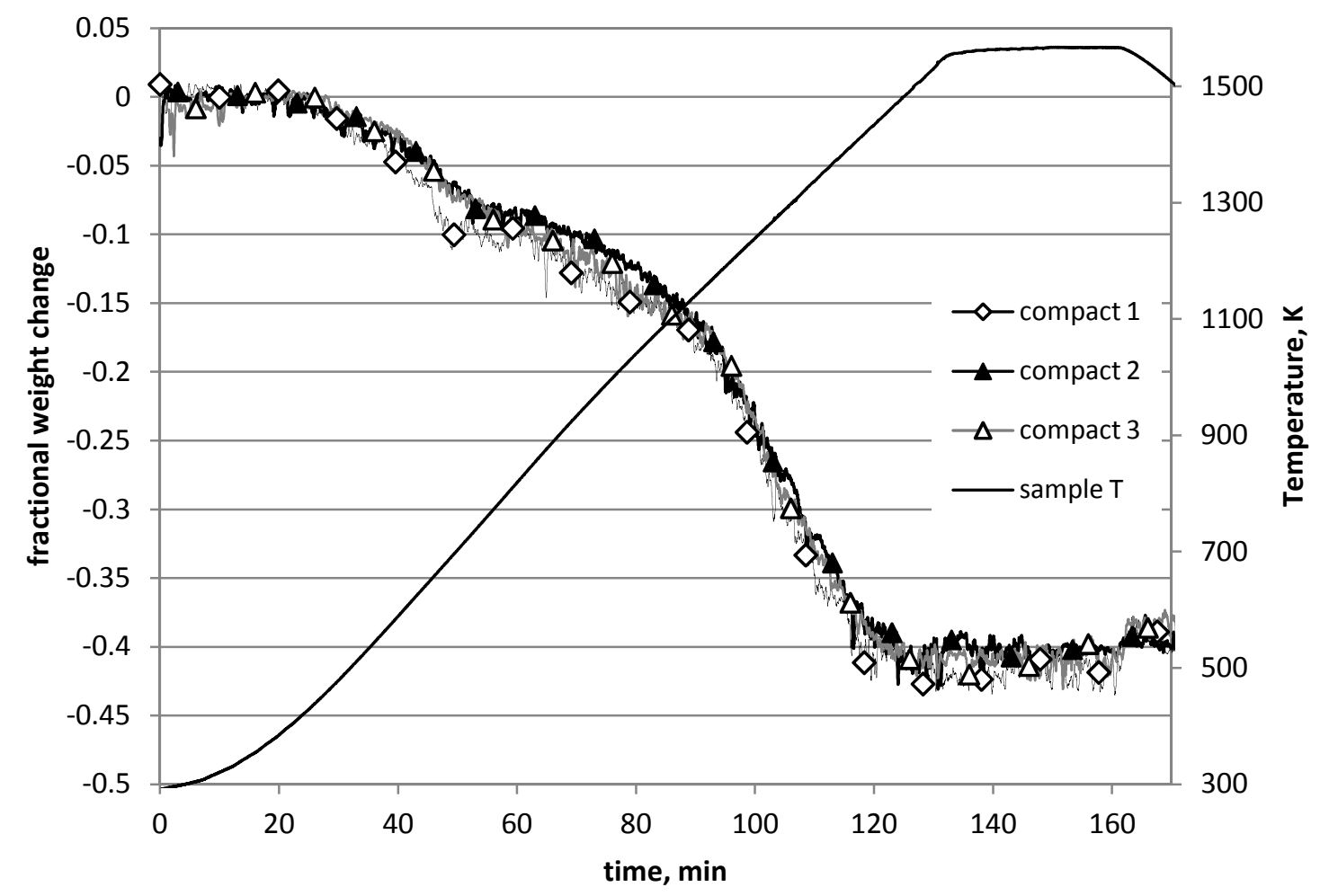

Figure 3 - Weight change curves for compacts of different types reduced at $1573 \mathrm{~K}$. 


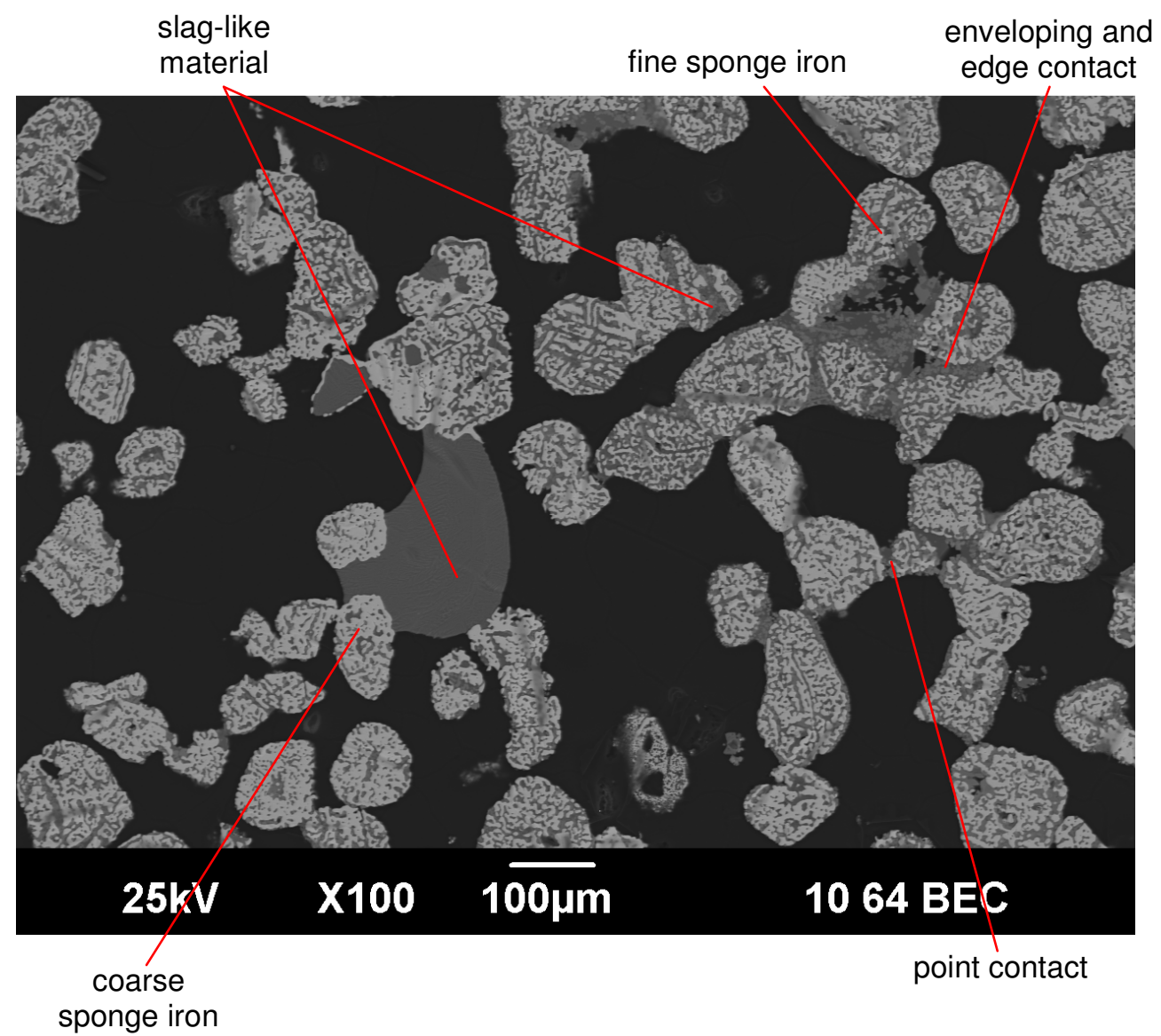

Figure 4 - Higher magnification SEM image of compact \#1 reduced at 1573K, showing sponge iron, slag-like material holding remnant ironsand particles together. 


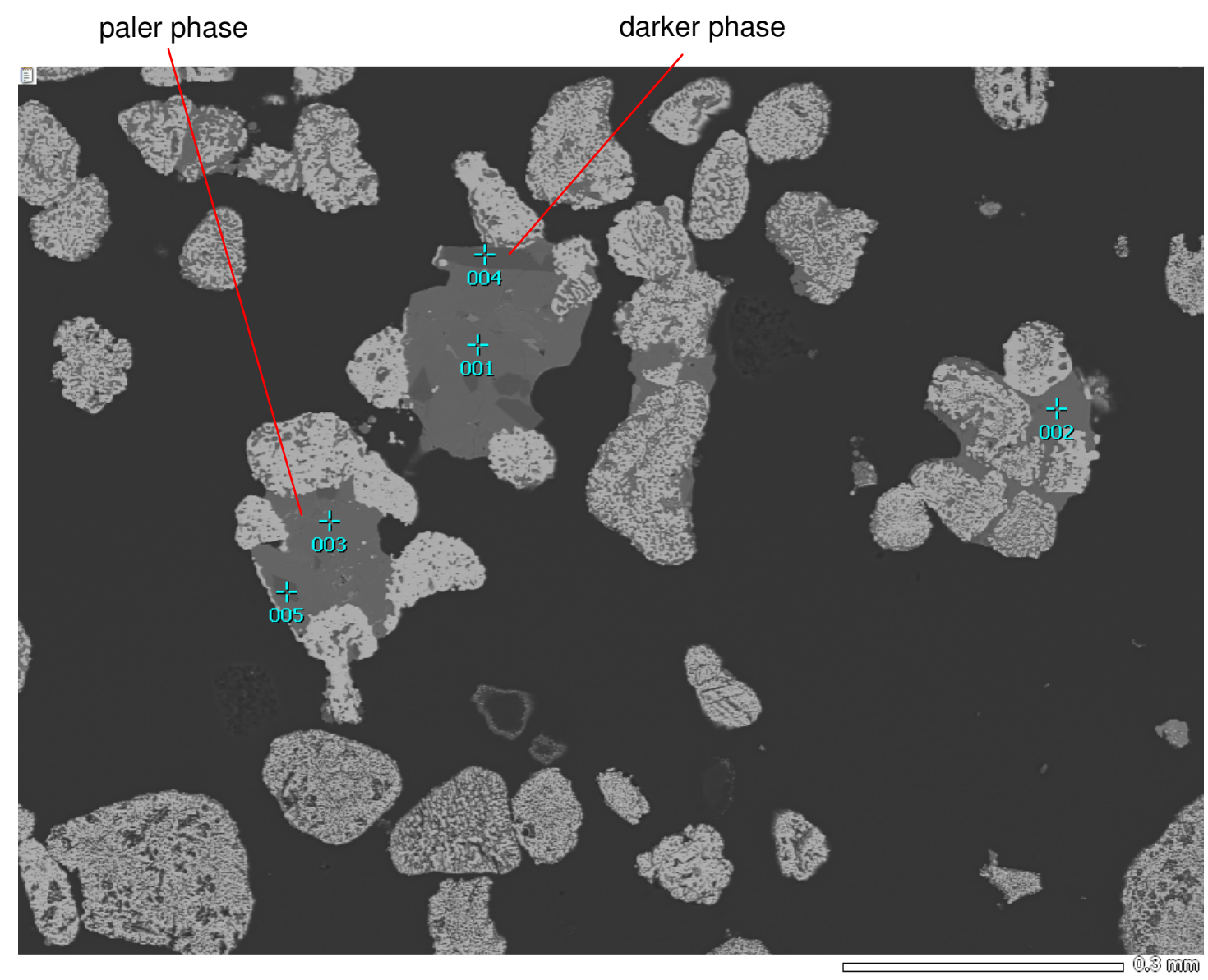

\begin{tabular}{|l|l|l|l|l|l|l|}
\hline Point & $\mathbf{O}$ & $\mathbf{M g}$ & $\mathbf{A l}$ & $\mathbf{S i}$ & $\mathbf{C a}$ & $\mathbf{T i}$ \\
\hline 1 & 60.6 & 6.0 & 4.4 & 14.5 & 10.2 & 4.3 \\
\hline 2 & 58.0 & 6.6 & 2.6 & 15.7 & 17.1 & 0.0 \\
\hline 3 & 59.2 & 9.7 & 7.3 & 10.1 & 7.7 & 6.0 \\
\hline 4 & 61.9 & 25.2 & 0.2 & 12.1 & 0.5 & 0.2 \\
\hline 5 & 61.3 & 25.9 & 0.1 & 11.9 & 0.6 & 0.1 \\
\hline
\end{tabular}

Figure 5 -Elemental analysis points within a compact \#1 sample reduced at 1573K. Semiquantitative analysis in atomic percent. 


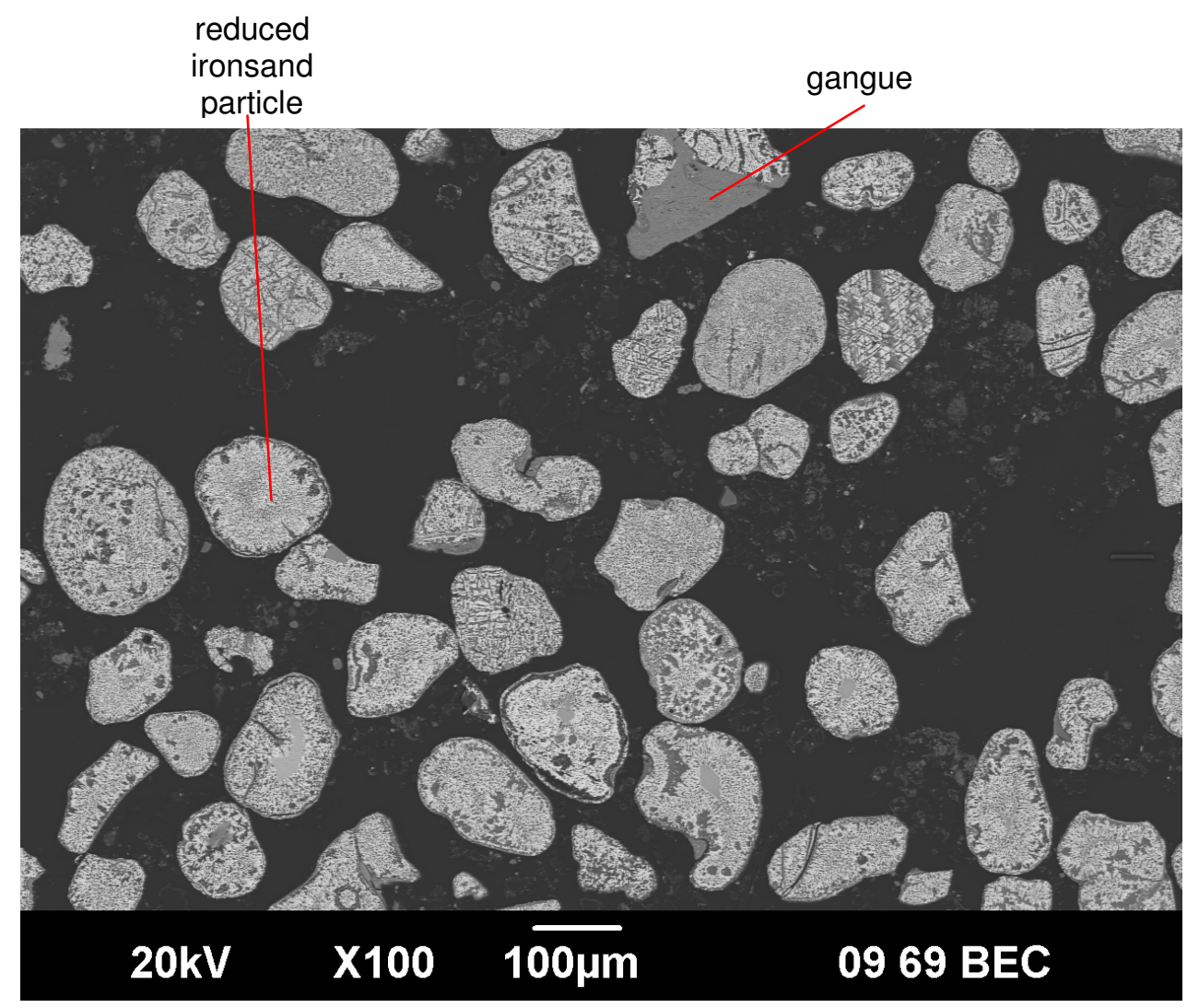

Figure 6(a)

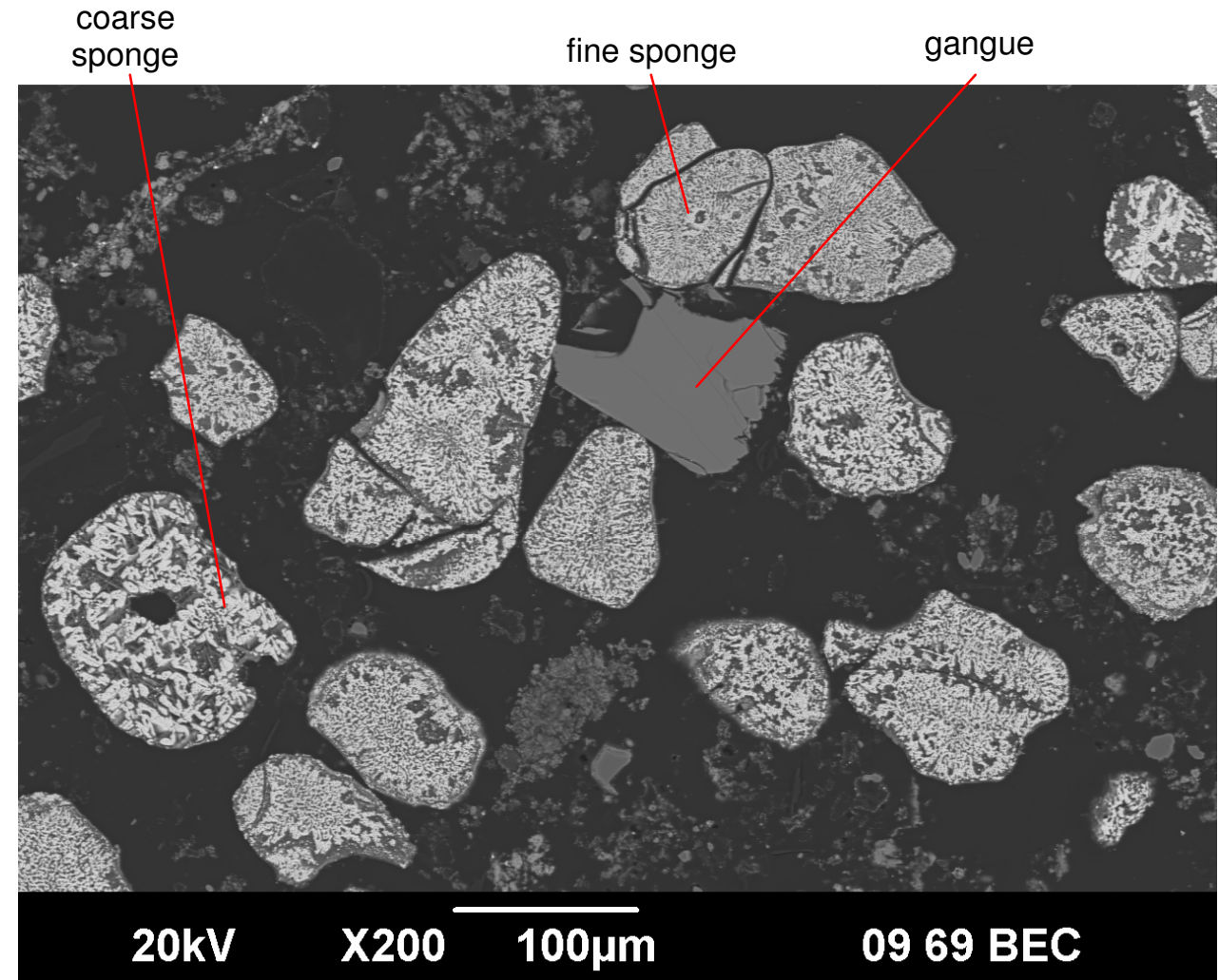

Figure 6(b)

Figure 6 - SEM images of reduced compact \#1 samples. (a) Reduced at 1273K, medium magnification overview showing reduced ironsand and coal remnants; (b) reduced at $1373 \mathrm{~K}$, 
medium magnification image showing sponge iron structure, gangue particles and carbonaceous material. 
partially

reduced

particle

slag-like

material

paler oxide

phase

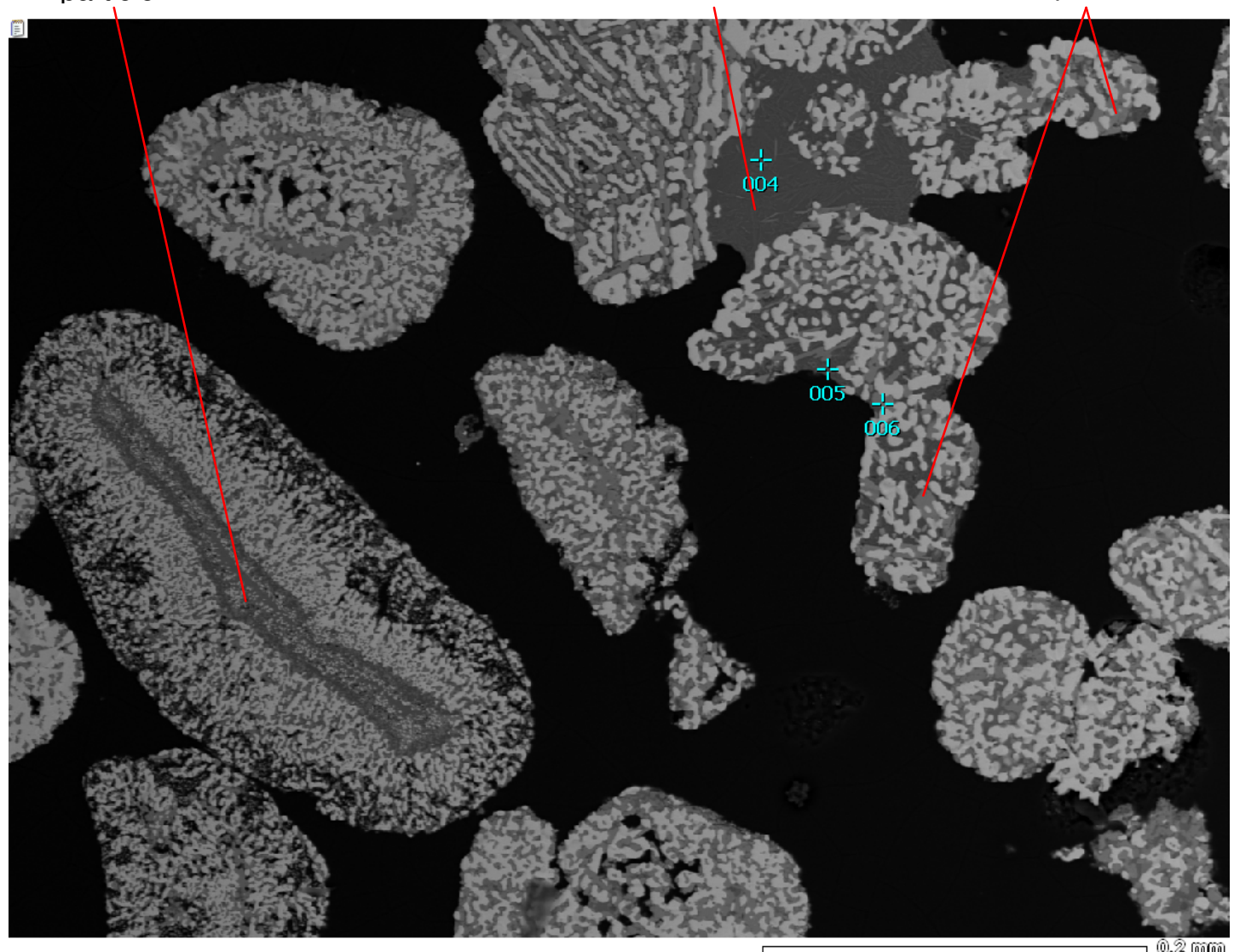

\begin{tabular}{|l|l|l|l|l|l|l|l|l|l|}
\hline Point & $\mathbf{C}$ & $\mathbf{O}$ & $\mathbf{M g}$ & $\mathbf{A l}$ & $\mathbf{S i}$ & $\mathbf{C a}$ & $\mathbf{T i}$ & $\mathbf{M n}$ & $\mathbf{F e}$ \\
\hline 4 & - & 62.8 & 1.1 & 3.6 & 26.4 & 0.7 & 1.8 & - & 3.6 \\
\hline 5 & - & 60.5 & 4.2 & 2.8 & 22.9 & 4.6 & 1.8 & - & 3.2 \\
\hline 6 & - & 47.3 & 5.2 & - & - & - & 26.5 & 1.4 & 19.6 \\
\hline
\end{tabular}

Figure 7 - SEM image of a compact \#1 sample reduced at 1473K. Medium magnification

showing sponge structure of reduced and partially reduced ironsand. Semi-quantitative analysis in atomic percent. 


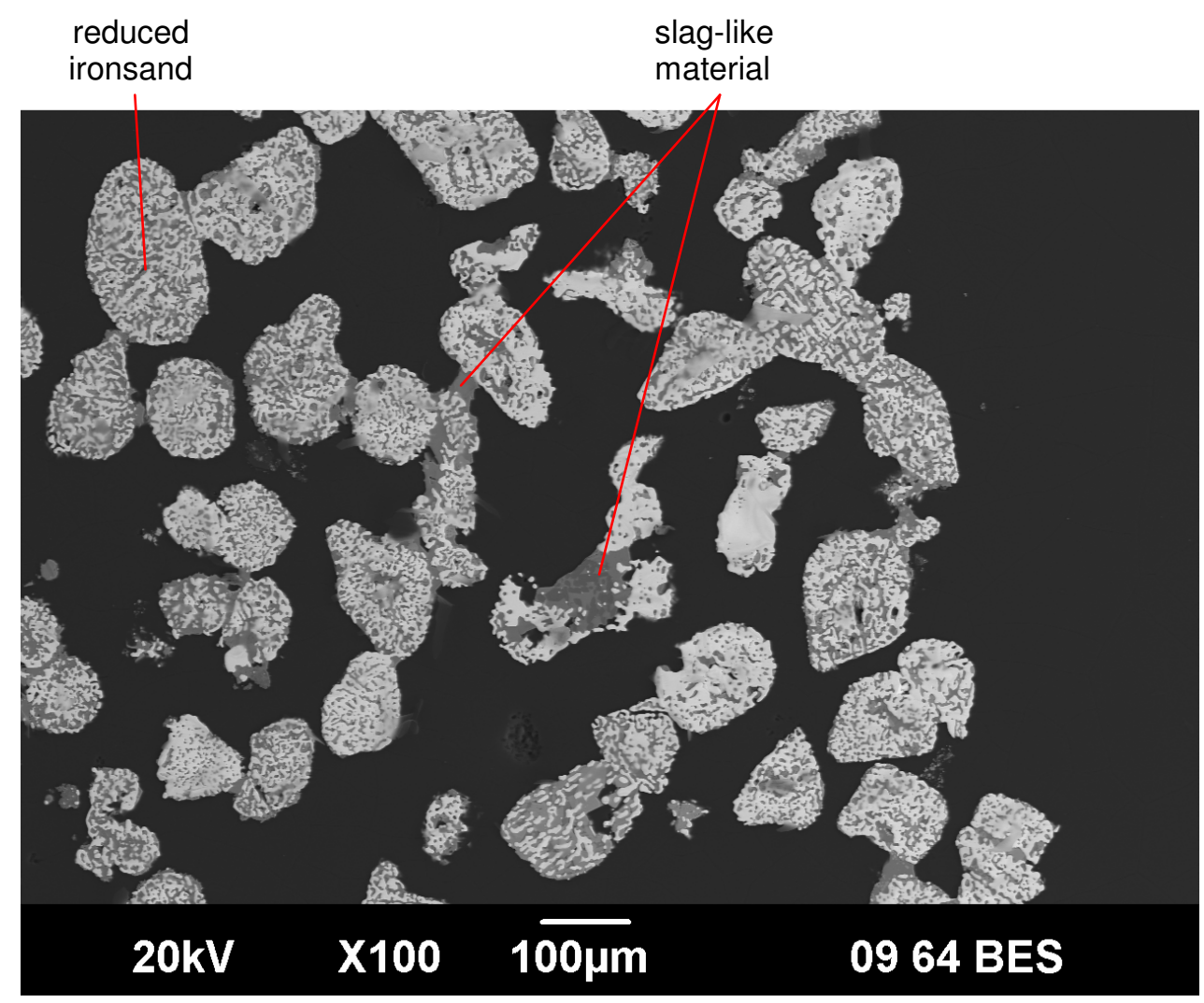

Figure 8 - Higher magnification SEM image of a compact \#2 sample reduced at $1573 \mathrm{~K}$.

Medium magnification image showing slag-like material binding reduced ironsand particles. 


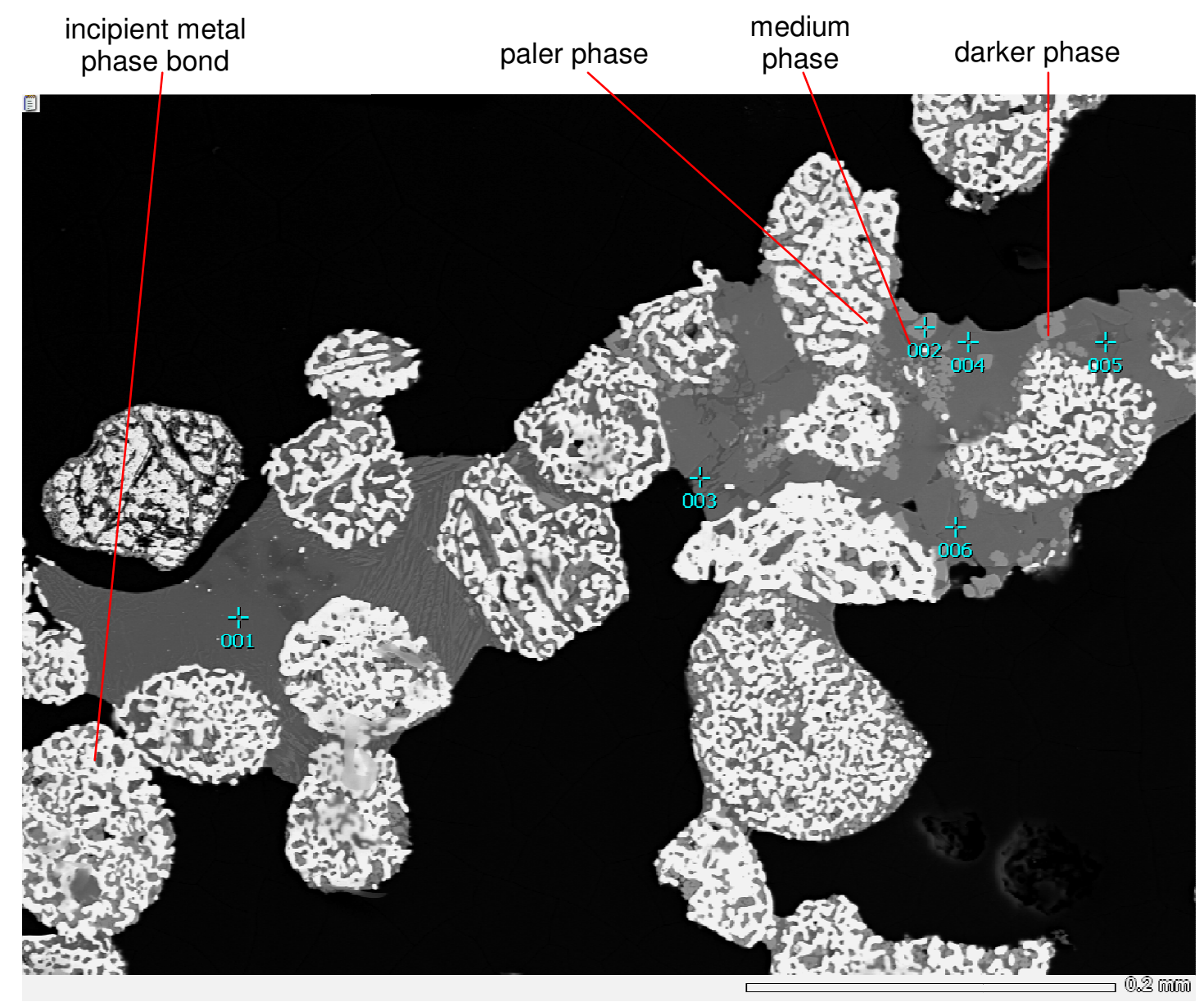

\begin{tabular}{|l|l|l|l|l|l|l|l|l|l|l|}
\hline Point & $\mathbf{O}$ & $\mathbf{N a}$ & $\mathbf{M g}$ & $\mathbf{A l}$ & $\mathbf{S i}$ & $\mathbf{K}$ & $\mathbf{C a}$ & $\mathbf{T i}$ & $\mathbf{M n}$ & $\mathbf{F e}$ \\
\hline 1 & 63.1 & 2.4 & 1.3 & 5.0 & 23.3 & 4.0 & - & 0.3 & 0.3 & 0.2 \\
\hline 2 & 58.5 & - & - & - & - & - & 20.3 & 21.2 & - & - \\
\hline 3 & 60.4 & 5.3 & 1.1 & 10.3 & 15.8 & 4.3 & 1.3 & 0.3 & 0.8 & 0.4 \\
\hline 4 & 57.3 & - & 11.2 & 9.2 & 8.5 & - & 5.7 & 7.3 & 0.6 & 0.1 \\
\hline 5 & 60.4 & - & 25.1 & 0.2 & 12.2 & - & 0.4 & 0.2 & 1.3 & 0.2 \\
\hline 6 & 60.5 & 5.6 & 1.7 & 8.3 & 14.9 & 3.3 & 3.1 & - & 2.7 & - \\
\hline
\end{tabular}

Figure 9 - EDS elemental analysis of points within a compact \#3 sample reduced at 1573K.

Semi-quantitative analysis given in atomic percent. 